\title{
Some Properties of Thyroidal Membrane Adenosinetri- phosphatase and Iodide Uptake: Effects of Basic Polyamino Acids
}

\author{
Jun KAWADA, Yoshiyuki YOSHIMURA AND TAKeshi MINAMI \\ Department of Biochemistry, Faculty of Pharmaceutical \\ Sciences, University of Tokushima, Tokushima-shi 770
}

\begin{abstract}
Synopsis
Poly L-lysine, poly L-ornithine, and histone significantly inhibited the iodide uptake by the thyroid slices, as previously reported. These basic polymers diminished Na, K-ATPase and concomitantly markedly elevated Mg-ATPase activity in the NaI-treated microsomal preparation and the plasma membrane fraction obtained from thyroid. Poly L-glutamic acid, which was noneffetive to the iodide uptake in vitro, did not show such phenomenon. K-dependent p-nitrophenylphosphatase activity which is considered to reflect the terminal step of the reaction sequence of $\mathrm{Na}$, K-ATPase was also inhibited by poly L-lysine. The effects mentioned above of poly L-lysine and other basic polyamino acids on membrane ATPase system were only found in the preparations from thyroid. The inhibitory effect of these reagents on thyroidal iodide uptake was discussed in terms of the change in membrane ATPase activities.
\end{abstract}

It was reported that the basic protein of cobra venom, Cobramine B, and other basic polyamino acids were the potent inhibitors of the iodide uptake by the thyroid gland and other iodide-concentrating tissues in vitro. Efflux of anion from the cells was increased and the cells became leaky toward potassium ion (Wolff et al., 1968). The lytic effect of these basic polymers was also suggested (Williams and Wolff, 1971). However, the precise mechanism of the effect of these basic substances has not been elucidated. On the other hand, uptake of iodide by the thyroid is thought to be closely related to ouabain-sensitive $\mathrm{Na}, \mathrm{K}$ ATPase of follicular cells (Wolff and Halmi, 1963). Although it has been shown that basic proteins or polyamino acids exhibit various effects on a variety of biological systems (Schwartz, 1965; Mayhew et al., 1973 ; Sato and Ullrich, 1975; Schneeman

$\overline{\text { Received for publication January 12 }}, 1976$. and Krogmann, 1975), no study has been done on the membrane transporting ATPase system. The present paper reports the observation that some kinds of basic polyamino acids specifically affected the activities of thyroidal membrane ATPase, and the inhibitory effect of these reagents on thyroidal $\mathrm{T} / \mathrm{M}\left[\mathrm{I}^{-}\right]$is discussed in terms of the change in membrane ATPase activities.

\section{Materials and Methods}

Fresh hog thyroid glands were obtained from a local slaughter house. After trimming, the glands were minced and homogenized twice for $20 \mathrm{sec}$ periods with an equal volume of chilled $0.25 \mathrm{M}$ sucrose solution containing $1 \mathrm{mM}$ EDTA ( $\mathrm{pH}$ 7.4) in a Waring blendor. The material was then homogenized with a Teflon homogenizer. The NaItreated microsomal fraction was obtained according to the flow diagram shown in Fig. 1. The treatment with NaI was done by the method of Nakao et al. (1965). A partially purified plasma membrane fraction was obtained by discontinuous sucrose density gradient centrifugation. For this, material 
in the $10,500 \times g$ pellet was placed on layers of $0.32 \mathrm{M}$ and $1.2 \mathrm{M}$ sucrose. After centrifugation at $100,000 \times g$ for $60 \mathrm{~min}$, the band at the boundary between two concentrations of sucrose was collected, suspended in an equal volume of $1 \mathrm{mM} \mathrm{NaHCO}_{3}$ solution and centrifuged at $20,000 \times g$ for $30 \mathrm{~min}$. The resulted pellet was resuspended in $0.25 \mathrm{M}$ sucrose solution, and used as the plasma membrane fraction. This fraction was also examined with electron microscope and was observed to be at least free from mitochondria. Therefore, the activity change in mitochondrial ATPase with polycations could be neglected in this fraction (Schwartz, 1965). Both NaI-treated microsomal fraction and partially purified plasma membrane fraction was the sample for the ATPase assay. Microsomal fractions treated with $\mathrm{NaI}$ from various other tissues were prepared in the same way.

$\mathrm{Na}, \mathrm{K}$-ATPase and Mg-ATPase activities were measured as described by Bonting et al. (1961). K-

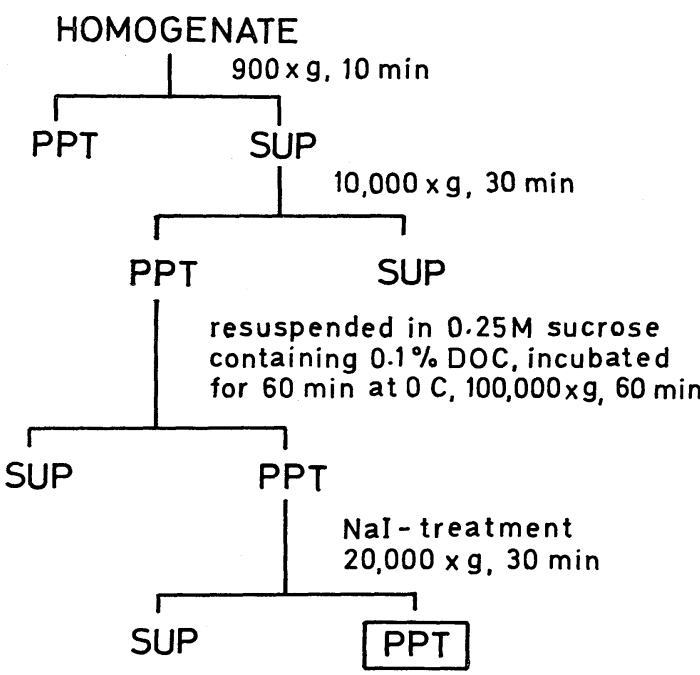

Fig. 1. Flow diagram of the method of enzyme preparation (NaI-treated microsomal fraction) from hog thyroid. dependent p-nitrophenylphosphatase (PNPase) activity was determined by the method previously reported (Tanaka and Mitsumata, 1969). Enzyme preparation was preincubated with polyamino acids for $30 \mathrm{~min}$ at $37^{\circ} \mathrm{C}$ prior to the enzyme assay. Protein concentration was measured by the method of Lowry et al. (1951).

In vitro study of iodide uptake was performed using hog thyroid slices preincubated for $1 \mathrm{hr}$ at $4^{\circ} \mathrm{C}$ in a Krebs-Ringer phosphate buffer ( $\mathrm{pH} 7.4$ ) prior to the determination (Wolff, 1972). Basic polyamino acids were added to the iodide-uptake reaction system without preincubation.

Poly L-lysine (approx. mol. wt. 100,000), poly L-ornithine (approx. mol. wt. 120,000) and histone (Type II-A) were all purchased from Sigma, pnitrophenylphosphate was from Wako, Tokyo. Poly L-glutamic acid (approx. mol. wt. 100,000) was kindly supplied by Dr. S. Yamashita of our institute. All other reagents were the analytical grade.

\section{Results}

Effects of basic polyamino acids on $T / M$ $\left[I^{-}\right]$:

As shown in Table 1, poly L-lysine, poly L-ornithine, and histone strongly inhibited iodide uptake of hog thyroid in vitro at the concentration of $400 \mu \mathrm{g} / \mathrm{m} l$. While, the same concentration of acidic polyamino acid, poly L-glutamic acid, had no effect on $\mathrm{T} / \mathrm{M}$ ratio. Dose-dependent curve of the

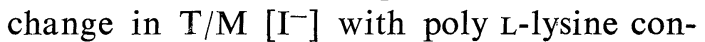
centration is shown in Fig. 2. These results coincided with the one previously reported (Wolff et al., 1968), though experimental conditions were somewhat different from each other.

Table 1. Effect of polyamino acids on $\mathrm{T} / \mathrm{M}\left[\mathrm{I}^{-}\right]$of hog thyroid slices in vitro.

\begin{tabular}{|c|c|c|c|c|}
\hline & $\begin{array}{l}\text { Approx. } \\
\text { mol. wt. }\end{array}$ & $\mu \mathrm{g} / \mathrm{m} l$ & $10^{-6} \mathrm{M}$ & $\begin{array}{c}\mathrm{T} / \mathrm{M}\left[\mathrm{I}^{-}\right] \\
(\% \text { control) }\end{array}$ \\
\hline Control & & & & 100 \\
\hline Poly L-lysine & $10^{5}$ & 400 & 4 & 48 \\
\hline Poly L-ornithine & $1.2 \times 10^{5}$ & 400 & 3.3 & 32 \\
\hline Histohe & $8.4 \times 10^{3}-5.5 \times 10^{4 *}$ & 400 & - & 31 \\
\hline Poly L-glutamic acid & $10^{5}$ & 400 & 4 & 100 \\
\hline
\end{tabular}

* from Data for Biochemical Research (edited by R. M. C. Dawson

et al.) Clarendon Press, Oxford, 2nd Ed. 1969.

$\mathrm{T} / \mathrm{M}^{\left[\mathrm{I}^{-}\right]}$value in control group was $41.5 \pm 1.9$ (Mean \pm S.E.). 
Effect of basic polyamino acids on thyroid microsomal ATPase preparation:

The effect of poly L-lysine, poly Lornithine, and histone on thyroid NaItreated microsomal ATPase activity was studied. The amount of these reagents examined was $300 \mu \mathrm{g}$ per tube and this amount was the same as that of enzyme protein (denoted as $1 / 1$ in Fig. 3 ). $\mathrm{Na}, \mathrm{K}$ ATPase was much reduced and Mg-ATPase was significantly increased in their specific activities. Lysine and poly L-glutamic acid, which were shown to be noneffective for

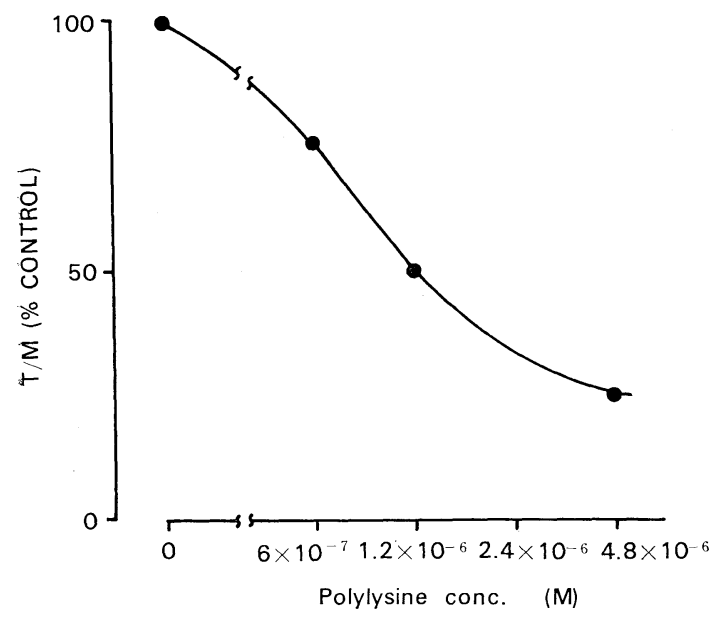

Fig. 2. Dose-response curve showing the inhibitory effect of poly L-lysine (approx. mol. wt. 100,000) on the iodide uptake by hog thyroid slices. T/M $\left[\mathrm{I}^{-}\right]$value in control group was $32.4 \pm 2.6$ (Mean \pm S.E.)
$\mathrm{T} / \mathrm{M}\left[\mathrm{I}^{-}\right]$, had no influence on both ATPase activities.

Effect of poly L-lysine on the ATPase preparation from thyroid and various other tissues:

Effect of poly L-lysine was studied extensively. As exemplified in Table 2, when

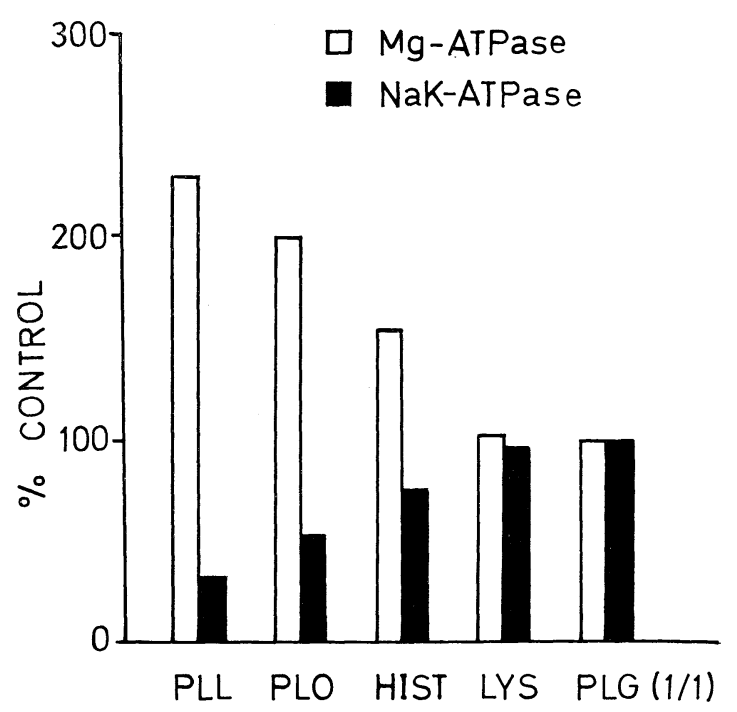

Fig. 3. Effects of poly L-lysine (PLL), poly Lornithine (PLO, approx. mol. wt. 120,000), histone (HIST), lysine, and poly L-glutamic acid (PLG, approx. mol. wt. 100,000) on the activities of thyroidal NaI-treated microsomal ATPase. The amount of each of the reagents is $300 \mu \mathrm{g}$ per tube which is equivalent to the amount of enzyme protein as indicated $1 / 1$. Na, K-ATPase and $\mathrm{Mg}$ ATPase activities in control were 17.1 and $5.0 \mu \mathrm{g}$ $\mathrm{Pi} / \mathrm{mg}$ protein $/ \mathrm{hr}$, respectively.

Table 2. Effect of poly L-lysine (PLL) on ATPase activities in thyroid and other tissues (\% control).

\begin{tabular}{|c|c|c|c|c|c|c|c|c|c|c|c|}
\hline \multirow{2}{*}{\multicolumn{2}{|c|}{$\begin{array}{l}\text { PLL/enzyme protein : } \\
\text { (300 } \mu \mathrm{g} \text { per tube })\end{array}$}} & \multicolumn{2}{|c|}{$10 / 1$} & \multicolumn{2}{|c|}{$1 / 1$} & \multicolumn{2}{|c|}{$1 / 10$} & \multicolumn{2}{|c|}{$1 / 100$} & \multicolumn{2}{|c|}{$\begin{array}{l}1 / 1000 \\
1 / K\end{array}$} \\
\hline & & $\mathrm{Na}, \mathrm{K}-$ & Mg- & $\mathrm{Na}, \mathrm{K}$ & $\mathrm{Mg}-$ & $\mathrm{Na}$ & Mg- & $\mathrm{Na}$, & $\mathrm{Mg}-$ & $\mathrm{Na}$, & $\mathrm{Mg}-$ \\
\hline \multirow{3}{*}{ Thyroid } & & 20 & 210 & 35 & 275 & 45 & 150 & 100 & 145 & 100 & 155 \\
\hline & hog & & & 40 & 2051) & & & & & & \\
\hline & hog & 26 & $26^{2)}$ & 43 & $42^{3)}$ & 97 & $63^{4)}$ & & & & \\
\hline \multirow[t]{2}{*}{ Kindney } & rat & & & 64 & 97 & 88 & 106 & 110 & 90 & & \\
\hline & mouse & & & 83 & 65 & 77 & 85 & & & & \\
\hline Brain & rat & 9 & 100 & 43 & 105 & & & & & & \\
\hline
\end{tabular}

The changes in the enzyme activities with PLL-treatment are expressed as percent of each specific activity of $\mathrm{Na}, \mathrm{K}-\mathrm{ATPase}(17.1 \mu \mathrm{g} \mathrm{Pi} / \mathrm{mg}$ protein $/ \mathrm{hr})$ and $\mathrm{Mg}$-ATPase $(5.0 \mu \mathrm{g} \mathrm{Pi} / \mathrm{mg}$ protein $/ \mathrm{hr}$ ) determined without PLL. All samples are NaI-treated microsomal fraction except 1). 1) is plasma membrane fraction ( $\mathrm{Na}, \mathrm{K}$-ATPase: $7.7 \mu \mathrm{g} \mathrm{Pi} / \mathrm{mg}$ protein/hr, Mg-ATPase: $11.1 \mu \mathrm{g} \mathrm{Pi} / \mathrm{mg}$ protein $/ \mathrm{hr}) .2,3)$ and 4 ) indicate the values obtained with PLL/enzyme ratio of $2 / 1,1 / 5$, and $1 / 50$, respectively. 
the amounts of poly L-lysine were changed from $1 / 1,000$ - to 10 -times of enzyme protein, the decrease in Na, K-ATPase activity and the increase in Mg-ATPase activity were observed in some extent in a dose-dependent manner. However, the maximum change in $\mathrm{Mg}$-ATPase activity was obtained at the ratio of $1 / 1$ of poly $\mathrm{L}$-lysine to enzyme protein. When the amounts of poly L-lysine were reduced, e.g. $1 / 100$ to $1 / 1,000$ of enzyme protein, $\mathrm{Mg}$-ATPase activity increased 1.5-fold with no change of $\mathrm{Na}, \mathrm{K}$ ATPase activity. The change in ATPase activities in plasma membrane fraction showed similar tendency as in microsomal fraction.

On the contrary, kidney and brain preparations showed only decreased or unchanged activities of Mg-ATPase and no significant elevation was observed in any conditions. Na, K-ATPase was consistently inhibited except at very small amounts of poly L-lysine. Therefore, increase of $\mathrm{Mg}$ ATPase activity with poly L-lysine observed in the preparation from thyroid seemed to be specific phenomenon with this tissue.

\section{Effect of poly L-lysine on K-dependent PNPase activity:}

Poly L-lysine significantly inhibited Kdependent PNPase activity, which is considered to reflect the terminal step of the $\mathrm{Na}, \mathrm{K}$-ATPase reaction, i.e. the K-depedent dephosphorylation of the phosphorylated enzyme (Askari and Koyal, 1968). The inhibition was about $50 \%$ at the ratio of $1 / 1$ of poly L-lysine to enzyme protein. Kidney preparation did not show any significant decrease in this enzyme activity with poly L-lysine in the same conditions (data not shown).

\section{Discussion}

Basic polyamino acids inhibited the iodide uptake of thyroid in vitro. The same reagents also decreased $\mathrm{Na}, \mathrm{K}$-ATPase acti- vity and concomitantly elevated Mg-ATPase activity of the thyroid microsomal fraction and plasma membrane. No increase of $\mathrm{Mg}$ ATPase activity was observed in the preparations from tissues other than thyroid. Acidic poly L-glutamic acid had influence neither on iodide uptake nor on $\mathrm{Na}, \mathrm{K}$ ATPase and Mg-ATPase activities. Although the lytic effect of positively charged polymers was suggested (Williams and Wolff, 1971), such effect was not observed in our experiment using mouse thyroid by the method of Brown and Munro (1967) (unpublished). Furthermore, the concept of the term "lysis" seems somewhat obscure and it would comprise many processes occurring at the cell membranes. Therefore, the results obtained here could not exclude the possible explanation that inhibitory effect of basic polyamino acids on iodide uptake might be mediated by the change in membrane Na, K-ATPase activity. However, the mechanism of decrease in $\mathrm{Na}, \mathrm{K}$ ATPase activity with basic polyamino acids is only speculative at present. Although the relation between $\mathrm{Na}$, K-ATPase activity and Mg-ATPase activity, and also the biochemical meaning of Mg-ATPase are still unknown, two assumptions are at least possible on the membrane ATPase; 1) Na, KATPase and Mg-ATPase are different entities and functionally independent from each other. 2) Both activities reside in a single molecule and they are enevitably correlated. If we take the second concept and could assume that basic polyamino acids cause any configurational change(s) on the ATPase protein, the significant decrease in $\mathrm{Na}, \mathrm{K}$-ATPase activity accompanied by the alterations of Mg-ATPase and K-dependent PNPase activities observed on the preparations from thyroid might be explained as follows using the modified conventional reaction sequence of the transporting enzyme (Robinson, 1970) shown in Fig. 4. 1) A change in configuration would make the enzyme protein difficult to be 
phosphorylated under the presence of sodium ion (Step 2). In such situation, hydrolysis of E-ATP complex is preferential and increased Mg-ATPase activity is observed (Step. 2'). The decrease in K-dependent PNPase activity is thought to be the second effect in this case. 2) Primary effect of basic polyamino acids through configurational change resides in potassium ion dependent dephosphorylation of phosphorylated enzyme protein which is observed as the K-dependent PNPase activity. The disturbance of the terminal reaction step (Step 4) might cause reduction of net $\mathrm{Na}, \mathrm{K}$-ATPase activity with resultant increase of $\mathrm{Mg}$ ATPase activity. The effect of basic polyamino acids on the rate of phosphorylated enzyme $(E \sim P)$ formation (Step 2) should be first examined to confirm these possible interpretations. This line of experiment is now progressing in our laboratory. The specific profile of thyroidal membrane ATPase toward positively charged polymers is probably due to the change(s) in the molecular environment such as phospholipids dependency surrounding the ATPase protein (Kimelberg, 1975), which provides the specific hydrophobic nature different from the membranes of other tissues. This problem is also awaited for future study.

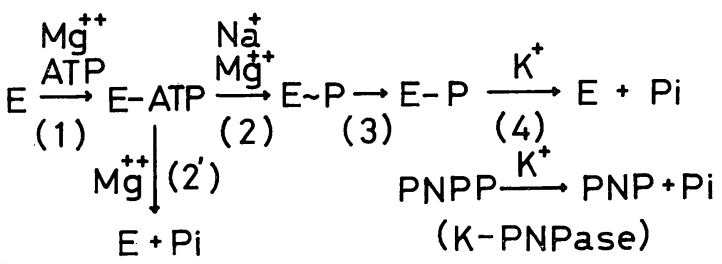

Fig. 4. Schematic representation of Na, K-ATPase reaction sequence. PNPP: p-nitrophenylphosphate, $\mathrm{Pi}$ : inorganic phosphate.

\section{References}

Askari, A. and D. Koyal (1968). Biochem. Biophys. Res. Commun. 32, 227.

Bonting, S. L., K. A. Simon and N. M. Hawkins. (1961). Arch. Biochem. Biophys. 95, 416.

Brown, J. and D. S. Munro (1967). J. Endocrinol. $38,439$.

Kimelberg, H. K. (1975). Biochim. Biophys. Acta $413,143$.

Lowry, O. H., N. J. Rosenbrogh, A. L. Farr and R. J. Randall (1951). J. Biol. Chem. 193, 265.

Mayhew, E., J. P. Horlos and R. L. Juliano (1973). J. Memb. Biol. 14, 213.

Nakao, T., K. Nagano, K. Adachi and M. Nakao (1965). Biochem. Biophys. Res. Commun. 19, 755.

Robinson, J. D. (1970). Arch. Biochem. Biophys. 139, 164.

Sato, K. and K. J. Ullrich (1975). J. Memb. Biol. 21, 311.

Schneeman, S. and D. W. Krogmann (1975). J. Biol. Chem. 250, 4965.

Schwartz, A. (1965). J. Biol. Chem. 240, 944.

Tanaka, R. and T. Mitsumata (1969). J. Neurochem. 16, 1163.

Williams, J. A. and J. Wolff (1971). Endocrinology 88, 206.

Wolff, J. Methods in Investigative and Diagnostic Endocrinology (edited by S. A. Berson). NorthHolland Publishing Co., Amsterdam and London, P. 115 (1972).

Wolff, J. and N. S. Halmi (1963). J. Biol. Chem. $238,316$.

Wolff, J., H. Salabe, M. Ambrose and P. R. Larsen (1968). J. Biol. Chem. 243, 1290. 